\title{
The influence of $\beta$-carotene supplementation on post-partum disease and subsequent reproductive performance of dairy cows in China
}

\author{
S.B. Bian ${ }^{1}$, R. Elliott ${ }^{2}$, I. Immig ${ }^{3}$ and D.F. Sun ${ }^{1,4}$ \\ ${ }^{1}$ College of Animal Science,Northwest Agriculture \& Forestry University \\ Yangling, Shaanxi, 712100, P.R. China \\ ${ }^{2}$ DSM Nutritional Products \\ Suite 6, 13 Princeton Street, Kenmore, Queensland, 4069, Australia \\ ${ }^{3}$ DSM Nutritional Products \\ Bldg. 241/834, CH-4002 Basel, Switzerland
}

\begin{abstract}
The plasma $\beta$-carotene status of non lactating Holstein-Friesian cows in a commercial dairy was found to be deficient (mean $1.2 \mu \mathrm{g} / \mathrm{ml}$ ). Subsequently three experiments were conducted to evaluate the influence of 300 and $500 \mathrm{mg} \beta$-carotene supplementation per cow per day commencing 21 days prior to expected calving date and continuing for 70 days after calving on reproductive performance and periparturient health. There were considerable fluctuations in plasma $\beta$-carotene concentrations in cows around the time of calving in both supplemented and unsupplemented animals. However plasma concentrations tended to decrease as calving approached and where at their lowest 10 days after calving. $\beta$-carotene supplements significantly decreased the incidence of retained placenta, mastitis and reduced the days from calving to first heat.
\end{abstract}

KEY WORDS: Holstein-Friesian, $\beta$-carotene, reproductive performance

\section{INTRODUCTION}

Dairy production in China is involve intensively housed animals of high genetic merit (principally Holstein-Friesian) fed large amounts of cereal based concentrates. Unfortunately, forage quality is very poor and consists mainly of maize stover, maize stover silage, rice straw together with small amounts of hays. Although vitamin A supplements are now incorporated into the rations for intensively fed livestock, herbivores in the wild are dependant on a range of carotenes in feedstuffs to provide all their vitamin A requirements.

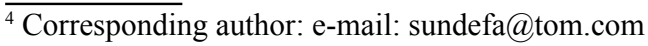


There is substantial evidence that circulating $\beta$-carotene plays an important role in improving the health and fertility of cattle and this role may be related to local biosynthesis of vitamin A in specific target organs such as the uterus, mammary gland and ovaries (Schweigert, 2003). It has also been demonstrated that $\beta$-carotene can enhance the immune response by potenciating lymphocyte and phagocyte function and thus decreases the incidence of periparturient disorders (Michal et al., 1994).

Based on the observations of Lotthammer et al. (1976) and Lotthammer and Ahlswede (1977) $\beta$-carotene supplementation programmes involving $300 \mathrm{mg} /$ head/day during the 3 weeks prior to calving and continuing until the subsequent pregnancy is confirmed have been widely adopted.

\section{MATERIAL AND METHODS}

Four experiments were conducted using Holstein-Friesian cows in a commercial dairy farm located in Shanghai, between December 2004-May 2005. In a preliminary evaluation (Experiment 1) blood samples were taken from 78 cows at dry off period to estimate plasma $\beta$-carotene. Subsequently, 2 experiments involving $\beta$-carotene supplementation were conducted each involving 75 multiparous cows approximately 21 days pre-partum which were randomly divided into 3 groups. Group 1 did not receive any $\beta$-carotene supplementation, Group 2 was supplemented with $300 \mathrm{mg} /$ head/day $\beta$-carotene and Group 3 received $500 \mathrm{mg} /$ head/day $\beta$-carotene.

Table 1. The composition of the diets in Experiments 2, 3 and 4

\begin{tabular}{lrrlcc}
\hline Ingredient, \% DM & Prepartum & Postpartum & Ration composition & Prepatum & Postpartum \\
\hline Maize silage & 23.70 & 17.31 & NEL, Mcal/kg DM & 1.46 & 1.48 \\
Lucerne hay & -- & 20.81 & CP, \%DM & 14.88 & 16.77 \\
Local grass hay & 32.15 & 12.5 & NDF, \%DM & 37 & 33 \\
Maize ground & 22.30 & 24.70 & $\mathrm{Ca}, \% \mathrm{DM}$ & 0.4 & 0.86 \\
Soyabean meal (43) & 7.68 & 8.88 & $\mathrm{P}, \% \mathrm{DM}$ & 0.41 & 0.43 \\
Cottonseed meal (40) & 6.00 & 4.96 & $\mathrm{RUP}, \% \mathrm{CP}$ & 40.6 & 37 \\
DDG (maize) & 4.27 & 4.93 & $\mathrm{~K}, \%$ & 1.42 & 1.45 \\
Wheat bran & 2.76 & 3.21 & $\mathrm{Mg}, \%$ & 0.22 & 0.24 \\
DCP & 0.50 & 0.49 & & & \\
Salt & 0.21 & 0.49 & & & \\
Limestone & -- & 0.74 & & & \\
Sodium bicarbonate & -- & 0.49 & & & \\
Premix & 0.43 & 0.49 & & & \\
\hline
\end{tabular}

the premix for lactating cows, IU/kg: vit. A 1500000, vit. D 250000; mg/kg: vit. E 6000, Fe 1000, $\mathrm{Cu}$ 3000, Mn 3000, Zn 14000, Co 30, I 200, Se 75

the premix for dry cows, IU/kg: vit. A 1100000 , vit. D 360000; mg/kg: vit. E 10000, Fe 1000, Cu 3000, Mn 3000, Zn 10000, Co 30, I 200, Se 75 
In the fourth experiment 76 multiparous cows were randomly divided into 2 groups. One group was supplemented daily with $300 \mathrm{mg} \beta$-carotene, the other group was the control. The diets fed to the cows were those used previously in Experiments 2 and 3. Supplementation again commenced 21 days before first expected calving date. In all 3 supplementation experiments the $\beta$-carotene (ROVIMIX ${ }^{\circledR} \beta$-carotene) was applied as a top dressing daily to each cow and mixed into the concentrate which was fed at the morning and evening milking. The $\beta$-carotene supplementation continued for 70 days after calving.

\section{Sampling and disease recording}

Blood samples $(10 \mathrm{ml})$ were collected from the jugular vein of each animal 4 times during Experiments 2 and 3, one time in Experiment 1. The first sample was taken immediately prior to $\beta$-carotene supplementation which commenced on day $21^{\text {th }}$ prior to expected calving date. Samples were also taken 7 days prepartum and at 10 days and again at 60 days post-partum. The blood samples were collected into heparinized tubes, centrifuged and the plasma decanted and stored at $-20^{\circ} \mathrm{C}$ for $\beta$-carotene estimation (HPLC).

A diagnosis of retained placenta in cows was made after a period of $48 \mathrm{~h}$ after parturition. The incidence of mastitis was determined by the presence of hot, hard quarters and the consistency of milk from each quarter. Reproductive health of the cows was monitored daily during the course of each experiment.

\section{RESULTS AND DISCUSSION}

In Experiment 1, there was a large range in plasma $\beta$-carotene concentrations after drying off (Figure 1). None of the cows exhibited plasma $\beta$-carotene concentrations above the level considered optimum $(3.5 \mu \mathrm{g} / \mathrm{ml})$.

In Experiment 2 there were considerable variations in the plasma $\beta$-carotene concentrations before and after calving. The cows not supplemented exhibited a decrease in plasma $\beta$-carotene content at day 7 prepartum and plasma concentrations continued to decrease and were at their lowest at $60^{\text {th }}$ day after calving (Table $2)$. In European studies both $\beta$-carotene and vitamin A concentrations in bovine plasma were observed to drop 2-3 weeks before parturition reaching a minimum at parturition. Normally 3-4 weeks are usually required before the concentrations of both substances return to previous levels (Schweigert, 1988).

Plasma $\beta$-carotene concentrations in cows in Experiment 3 actually rose in the period immediately before calving (Table 2). The base levels of $\beta$-carotene 21 days prior to calving in these cows however where the lowest observed in all the experiments reported here. However, the cows which received the highest level of $\beta$-carotene 


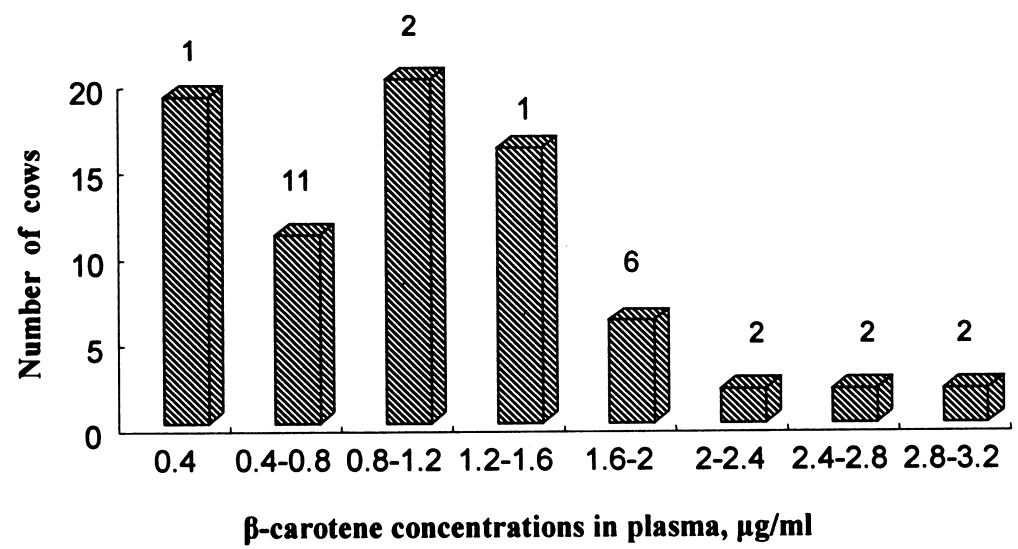

Figure 1. Distribution of $\beta$-carotene concentrations in plasma in dry cows

Table 2. The effect of supplementation with varying levels of $\beta$-carotene on plasma

\begin{tabular}{lcccc}
\hline \multirow{2}{*}{ Item } & \multicolumn{2}{c}{ Pre partum, day } & \multicolumn{2}{c}{ Post partum, day } \\
\cline { 2 - 5 } & -21 & -7 & 10 & 60 \\
\hline Experiment 2 & & & & \\
$\quad$ control, mg/d & $1.727^{\mathrm{b}}$ & 1.477 & $0.576^{\mathrm{a}}$ & $0.461^{\mathrm{a}}$ \\
300 & $1.010^{\mathrm{a}}$ & 1.290 & $0.899^{\mathrm{b}}$ & $1.014^{\mathrm{b}}$ \\
500 & $1.241^{\mathrm{a}}$ & 2.407 & $0.979^{\mathrm{b}}$ & $1.261^{\mathrm{b}}$ \\
& & & & \\
Experiment 3 & & & & \\
control, mg/d & 0.915 & 1.162 & 1.039 & $2.443^{\mathrm{a}}$ \\
300 & 0.989 & 1.282 & 0.980 & $2.548^{\mathrm{a}}$ \\
500 & 1.208 & 1.644 & 1.636 & $3.328^{\mathrm{b}}$ \\
\hline
\end{tabular}

values with different superscripts are significantly different $\mathrm{P}>0.05$

supplementation (500 $\mathrm{mg} /$ head/day) exhibited significantly higher plasma concentrations throughout the experiment. The cows supplemented with $300 \mathrm{mg} /$ day did not exhibit higher $\beta$-carotene concentrations above control animals.

Schweigert (1988) found that low density lipoprotein receptors in the mammary gland increased at the time of parturition and this event facilitated not only the transfer of $\beta$-carotene into colostrum but also that of cholesterol and the immunoglobulins. When true milk production replaced colostrum production this would therefore automatically lead to an elevation in plasma $\beta$-carotene concentrations.

A clear response to $\beta$-carotene supplementation in Experiments 2, 3 and 4 was the improvement in the reproductive health of the cows. Specifically there was a reduction in the incidence in retained placenta in Experiment 2 (Table 3) and Experiment 3 (Table 4) and a highly significant reduction in Experiment 4 (Table 5). A reduction in 
retained placenta due to $\beta$-carotene supplementation has been reported previously by Michal et al. (1994). It is now believed that retention of placenta is a result of the poor immunological status of the cow at calving (Lona and Romero, 2001).

Table 3. The effect of differing levels of $\beta$-carotene supplementation on post partum disease and reproduction (Experiment 2)

\begin{tabular}{lccc}
\hline Item & Days to first heat & Mastitis, \% & Retained placenta, \% \\
\hline Control & $80^{\mathrm{a}}$ & $13.6^{\mathrm{a}}$ & 40.9 \\
$300 \mathrm{mg}$ & $84^{\mathrm{a}}$ & $0.0^{\mathrm{b}}$ & 25.0 \\
$500 \mathrm{mg}$ & $72^{\mathrm{b}}$ & $4.3^{\mathrm{b}}$ & 34.8 \\
\hline
\end{tabular}

values with different superscripts are significantly different $\mathrm{P}>0.05$

Table 4. The effect of differing levels of $\beta$-carotene supplementation on post partum disease and first oestrus (Experiment 3)

\begin{tabular}{lccc}
\hline \multirow{2}{*}{ Item } & \multicolumn{2}{c}{ Post partum disease, \% } & \multirow{2}{c}{ days } \\
& retained placenta & dead foetus & $1^{\text {st }}$ oestrus \\
\hline Control & 27 & 10 & $79^{\mathrm{a}}$ \\
$300 \mathrm{mg} / \mathrm{d}$ & 19 & 0 & $76^{\mathrm{a}}$ \\
$500 \mathrm{mg} / \mathrm{d}$ & 18 & 0 & $71^{\mathrm{b}}$ \\
\hline
\end{tabular}

values with different superscripts are significantly different $\mathrm{P}<0.05$

Improved immunological status of the cow due to $\beta$-carotene supplementation is also suggested by the significant decrease in clinical mastitis observed in Experiment 2 (Table 3). Dahlquist and Chew (1985) had previously observed that cows supplemented daily with $300 \mathrm{mg}$ of $\beta$-carotene exhibited a significant reduction in milk somatic cell counts.

In Experiments 2 and 3, supplementation with $500 \mathrm{mg} \beta$-carotene reduced the days from calving to first heat. Moreover $58 \%$ of the supplemented cows in Experiment 4 exhibited oestrus and could be inseminated at 70 days post partum compared with only $39 \%$ of the unsupplemented cows (Table 5). Conception rates were also significantly higher in the $\beta$-carotene supplemented cows.

Table 5. The effect of $300 \mathrm{mg}$ of $\beta$-carotene supplementation on the reproductive performance and post partum disease (Experiment 4)

\begin{tabular}{lcccc}
\hline Item & $\begin{array}{c}\text { Cows with first } \\
\text { AI 70 pp, \% }\end{array}$ & $\begin{array}{c}\text { Conception rate 70 } \\
\text { days pp, \% }\end{array}$ & $\begin{array}{c}\text { Retained } \\
\text { placenta, \% }\end{array}$ & $\begin{array}{c}\text { Clinical } \\
\text { mastitis, \% }\end{array}$ \\
\hline Control & $39^{\mathrm{a}}$ & $24^{\mathrm{a}}$ & $26^{\mathrm{a}}$ & 36 \\
$300 \mathrm{mg} / \mathrm{d}$ & $58^{\mathrm{b}}$ & $36^{\mathrm{b}}$ & $8^{\mathrm{b}}$ & 19 \\
\hline
\end{tabular}

values with different superscripts are significantly different $\mathrm{P}>0.05$

$\beta$-carotene concentration increases in the bovine corpus luteum as the ovarian cycle progresses (Schweigert, 2003). Previously Ahlswede and Lotthammer (1978) 
had reported that depressions in progesterone production could be overcome by $\beta$-carotene supplementation but not vitamin A. There are reports of the failure of $\beta$-carotene supplementation to improve reproductive efficiency, it is significant in our experiments.

\section{REFERENCES}

Ahlswede L., Lotthammer K.H., 1978. Investigations on the specific vitamin A independent effect of $\beta$-carotene on the fertility of cattle. Deut. Tieraztl. Wochenschr. 85, 7

Dahlquist S.P., Chew B.P., 1985. Effects of vitamin A and B-carotene on mastitis in dairy cows during the early dry period. In : $80^{\text {th }}$ Annual Meeting of American Dairy Science Association 68, Suppl. 1, 191-192

Lona D.V., Romero R.C., 2001. Low levels of colostral immunoglobulins in some dairy cows with placental retention. J. Dairy Sci. 84, 389-391

Lotthammer K.H., 1979. Importance of ß-carotene for the fertility of dairy cattle. Feedstuffs 51, 34-36

Lotthammer K.H., Ahlswede L., 1977. Specific vitamin A independent effect of $\beta$-carotene on the bovine fertility. 3. Analysis of blood serum levels (ß-Carotene, vitamin A, SGOT, total cholesterol, glucose, inorganic phosphorus). Deut. Tieraztl. Wochenschr. 84, 220-226

Lotthammer K.H., Ahlswede L., Meyer H., 1976. Studies on a specific vitamin A unrelated effect of $\beta$-carotene on the fertility of cattle. 2. Further clinical findings and fertilization results (experiment III). Deut. Tieraztl. Wochenschr. 83, 353-358

Michal J.J., Heirman L.R.., Wong T.S., Chew B.P., Frigg M., Volker L., 1994. Modulatory effects of dietary $ß$-carotene on blood and mammary leukocyte function in periparturient dairy cows. J. Dairy Sci. 77, 1408-1421

Schweigert F.J., 1988. $\beta$-carotene transfer into colostrum in cows: Evidence of temporary increase in low-density lipoprotein receptors in mammary gland during formation of colostrum. In: $\mathrm{H}$. Berger (Editor). Vitamins and Minerals in Pregnancy and Lactation. Nestle Nutrition Workshop Series, Vol. 16. Raven Press Ltd., New York

Schweigert F.J., 2003. Changes in the concentration of $\beta$-carotene alpha-tocopherol and retinol in the bovine corpus luteum during the ovarian cycle. Arch. Anim. Nutr. 57, 307-310 